\title{
CES 部材に適用する繊維補強コンクリートの構造性能 STRUCTURAL PERFORMANCE OF FIBER-REINFORCED CONCRETE
APPLIED TO CES MEMBERS
}

藤本利昭*, 六田莉那子 **, 大崎広貴*** Toshiaki FUJIMOTO, Rinako ROKUTA and Hirotaka OSAKI

\begin{abstract}
Concrete-encased steel (CES) structural system consisting of fiber-reinforced concrete (FRC) and encased steels is a new composite structural system. Continuous and comprehensive studies are currently being conducted to make this system practical. In existing studies, the ultimate strength of CES columns was calculated using the strength superposition method. However, for CES columns in which FRC is used, the contribution of the confinement effect to the structural performance remains unclear. This study discusses the evaluation of the strength and confinement effect of FRC based on test results.
\end{abstract}

Keywords : CES, Fiber-Reinforced Concrete, Crack Strength, U Itimate Strength, Structural Performance $\mathrm{CES}$, 繊維補強コンクリート, ひび割れ強度, 終局耐力, 構造性能

\section{1. はじめに}

CES 構造とは Concrete Encased Steel 構造の略で, Fig.1 に示すよう に鉄骨鉄筋コンクリート（Steel Reinforced Concrete；以下，SRC）構 造の鉄筋コンクリート（Reinforced Concrete; 以下，RC）部を繊維 補強コンクリート（Fiber Reinforced Concrete；以下，FRC）に置き 換えた新しい建築合成構造システムである。日本建築学会では, 「CES 造建物の構造性能評価指針（仮称）」(以下，CES 指針）の刊 行を目標に, CES 構造に関する研究が継続的に行われている ${ }^{1)} こ$ れまでのCES 構造に関する研究では, 主として終局耐力や変形能力 に着目した柱 ${ }^{21-9)}$, 梁 ${ }^{10)}$ などの部材実験や, 部分架構（柱梁接合部） ${ }^{11)-17)}$ および架構実験 ${ }^{18)}$ が行われている。CES 部材の最大の特徵は前 述のとおり被覆 RC 部を無筋の FRC に置き換えていることであり, 鉄筋がないため内蔵鉄骨の断面せいや幅を大きくできるという利点 も有しているが，CES 部材の構造性能を適切に評価するためには， 被覆 FRC の構造性能, 更には合成部材としての相互作用効果を明ら かにすることが重要である。

そこで本研究では, 次に述べる FRC のひび割れ強度, 曲げ圧縮強 度, および FRC による内蔵鉄骨の座屈補剛効果の 3 点に着目した。 CES 指針では, 性能評価型設計を基本としており, CES 部材の使 用性, 耐久性, 損傷制御の観点からひび割れ強度の評価が重要と考
えられるが, CES 部材のひび割れ強度に着目した研究は殆どない。 そこでCES 部材の曲げひび割れ強度, せん断ひび割れ強度の評価方 法を確立するため, FRC のひび割れ強度を明確にした上で, CES 部 材のひび割れ強度を明らかにする。

またこれまでの研究で, CES 柱の終局曲げ耐力は日本建築学会「鉄 骨鉄筋コンクリート構造計算規準・同解説」19)（以下，SRC 規準） のコンクリート部と鉄骨部による一般化累加耐力式で, 評価できる ことが報告されている7) SRC 規準による一般化累加耐力式は, 鉄 骨については全塑性状態を仮定し，コンクリートについては引張強 度を無視し圧縮強度のみを考慮した長方形のストレスブロックを用
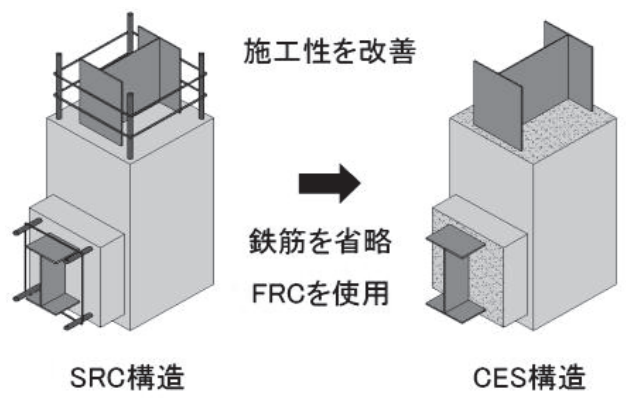

Fig.1 CES Structural System

\footnotetext{
* 日本大学生産工学部建築工学科 教授 $\cdot$ 博士 (工学)

** 大和八ウス工業株) 修士(工学)

*** $\begin{aligned} & \text { (元日本大学 大学院生) } \\ & \text { 日本大学大学院生産工学研究科建築工学専攻博士前期課程 }\end{aligned}$ 大学院生
}

\footnotetext{
Prof., Dept. of Architecture and Architectural Engineering, College of Industrial Technology, Nihon University, Dr.Eng.

Daiwahouse Industry Co., Ltd., M.Eng.

(Former Grad. Stud., Nihon University)

Grad. Stud., Graduate School of Industrial Technology, Nihon University
} 
いている。そのコンクリートのストレスブロックは, 応力分布（ひ ずみ分布）と鉄骨による断面欠損の影響をコンクリート強度の低減 係数 ${ }^{r}$ U で考慮していると考えられる。これらの仮定はSRC 部材を 対象として考えられていることから, 内蔵鉄骨に対しては被覆 RC 部による座屈拘束効果が, 被覆コンクリートに対しては横補強筋に よる拘束効果が間接的に考慮されている。よって SRC 規準式を CES 部材に適用するためには, 内蔵鉄骨と被覆 FRC それぞれの耐力分担 を明確にする必要があり, 補強筋により横拘束された被覆 RC 部に 対して設定されたストレスブロックが FRC に適用できることを確 認する必要がある。そこで FRC の曲げ圧縮特性と終局耐力の評価方 法の検討を行った。

更に SRC 構造では，被覆 RC 部の補剛効果により，内蔵鉄骨の座 屈補剛効果が認められることから, 純鉄骨部材に対して幅厚比の制 限值が緩和されている。これまでの CES 柱の実験では比較的幅厚比 の小さい内蔵鉄骨を用いていることから幅厚比の制限值は明確では なく, 今後の CES 構造の実用化を考えた場合, 内蔵鉄骨の幅厚比の 適用範囲についても明らかにする必要がある。そこで CES 柱の基本 的な構造性能を表す圧縮性状について, 内蔵鉄骨の幅厚比を実験変 数とした中心圧縮実験により, FRCによる内蔵鉄骨の座屈補剛効果 について検討を行った。

\section{FRC およびCES 部材のひび割れ強度の検討}

\subsection{FRC の実験概要}

一般的に FRC では, コンクリートの初期ひび割れ発生後, 繊維が ひび割れ面間を繋ぎ止め, ひび割れの進行を緩和させ脆性的な引張 破壊が防止される ${ }^{20)}$ 。よってひび割れ発生後の変形性能が大きく改 善されるが，その性状は繊維の種類や混入量により大きく変化する ことがわかっている ${ }^{211}$ 。そこでCES 構造に用いるFRC のひび割れ 強度を検討するため, 繊維混入前の普通コンクリート（ベースコン クリート)および繊維混入後の FRC の圧縮強度試験, 曲げ強度試験, 割裂引張試験を行った。

試験体および実験結果の一覧を Tablel に示す。試験体は, 文献 22) 〜25)に示した構造実験に際して製作したものである。試験体の FRC は, 普通コンクリートにビニロンファイバーRF4000 (直径 $0.66 \mathrm{~mm}$, 長さ $30 \mathrm{~mm}$ ）を体積混入率で $1 \%$ 混入して製作した。なお，Table1 に 示す值は, 各調合当たり 3 体行った実験結果の平均值を示している。

実験には $2000 \mathrm{kN}$ 万能試験機を使用し, Fig.2 に示寸ようにJIS に 基づき行った。試験体寸法は, 圧縮試験, 割裂引張試験は $100 \phi 200 \mathrm{~mm}$, 曲げ強度試験は $100 \times 100 \times 400 \mathrm{~mm}$ である。

Table1 Material properties of concrete and FRC

\begin{tabular}{|c|c|c|c|c|c|c|c|}
\hline $\begin{array}{l}\text { 調 } \\
\text { 合 }\end{array}$ & 種類 & $\begin{array}{c}\text { 設計基準 } \\
\text { 強度 } \\
F_{C} \\
\left(\mathrm{~N} / \mathrm{mm}^{2}\right)\end{array}$ & 材齢 & $\begin{array}{c}\text { 圧縮強度 } \\
\sigma_{\mathrm{B}} \\
\left(\mathrm{N} / \mathrm{mm}^{2}\right)\end{array}$ & $\begin{array}{c}\text { ヤング係数 } \\
E_{C} \\
\left(\mathrm{~N} / \mathrm{mm}^{2}\right)\end{array}$ & $\begin{array}{c}\text { 曲げ強度 } \\
\sigma_{\mathrm{b}} \\
\left(\mathrm{N} / \mathrm{mm}^{2}\right)\end{array}$ & $\begin{array}{c}\text { 引張強度 } \\
\sigma_{\top} \\
\left(\mathrm{N} / \mathrm{mm}^{2}\right)\end{array}$ \\
\hline \multirow{2}{*}{ (1) } & 普通 & \multirow{2}{*}{36} & \multirow{2}{*}{974 日 } & 51.9 & 31461 & 7.2 & - \\
\hline & FRC & & & 45.4 & 31173 & 7.1 & - \\
\hline (2) & 普通 & 36 & 902 日 & 49.3 & 28271 & 6.3 & - \\
\hline & 普通 & \multirow{2}{*}{27} & \multirow{2}{*}{560 日 } & 46.4 & 32548 & - & 3.2 \\
\hline & FRC & & & 46.4 & 30982 & - & 3.5 \\
\hline \multirow{2}{*}{ (4) } & $F R C$ & \multirow{2}{*}{27} & 36 日 & 31.9 & 29985 & - & 2.8 \\
\hline & PRC & & 174 日 & 39.1 & 26972 & 6.1 & - \\
\hline (5) & FRC & 27 & 58 日 & 31.7 & 27448 & 5.1 & 2.7 \\
\hline \multirow{2}{*}{ (6) } & 普通 & \multirow{2}{*}{27} & \multirow{2}{*}{133 日 } & 34.3 & 30654 & - & - \\
\hline & FRC & & & 31.8 & 28007 & 4.6 & 2.6 \\
\hline
\end{tabular}
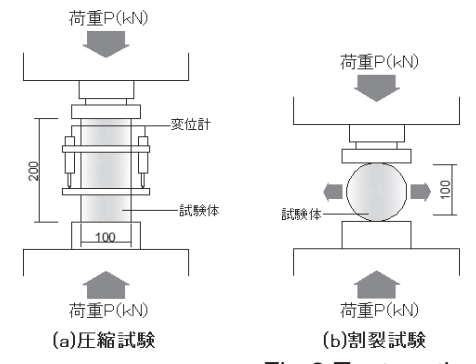

Fig. 2 Test method

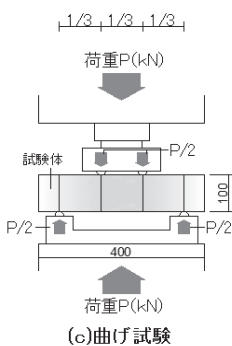

(c)曲げ試験

\section{2 検討に用いた式}

FRC ならびに CES 部材のひび割れ強度の評価方法を検討にあた り，既往のコンクリート系部材に用いられる式に基づき検討を行う こととした。

曲げひび割れ強度式は, 日本建築学会「鉄筋コンクリート構造計 算規準・同解説」 ${ }^{26)}$ (以下, RC 規準）の式(1)を用いた。

$M_{C r}=\sigma_{b} Z_{e}+\frac{N D}{6}$

ここで, $M_{\mathrm{cr}}$ ：曲げひび割れ強度， $\sigma_{b}$ ：コンクリート曲げ強度 $\left(=0.56 \sqrt{\sigma_{\mathrm{B}}}\right), \sigma_{\mathrm{B}}$ : コンクリート圧縮強度, $\mathrm{Z}_{\mathrm{e}}$ : 等価断面係数, $N$ : 作用軸力， D：断面せいである。

一方，せん断ひび割れ強度は，日本建築学会「鉄筋コンクリート 造建物の勒性保証型耐震設計指針」27)（以下，勒性指針）の式(2)を 用いた。

$\mathrm{V}_{\mathrm{SC}}=\sqrt{\sigma_{\mathrm{T}}^{2}+\sigma_{\mathrm{T}} \sigma_{0}} \cdot \mathrm{b} \cdot \mathrm{D} \cdot \frac{1}{\kappa}$

ここで, $\mathrm{V}_{\mathrm{sc}}$ ：せん断ひび割れ強度， $\sigma_{\mathrm{T}}$ ：コンクリート引張強度 $\left(=0.313 \sqrt{\sigma_{\mathrm{B}}}\right), \sigma_{0}$ : 軸応力度, $b$ : 断面幅, $\kappa$ : 形状係数（矩形断 面では 1.5) である。

ひび割れ強度の式(1)，(2)は普通コンクリートを用いた RC 部材を 対象とした算定式であり,これらの式の FRC との対応を実験により 検討した。

\section{$2.3 \mathrm{FRC}$ の各種強度}

a) 圧縮強度

Fig.3(a)に圧縮試験より得られた応力ーひずみ関係の一例を示す。 Fig.3(a)より，FRC は普通コンリートに繊維を混入することで，圧縮 強度が若干低下した。その一方で, FRC は最大荷重後の強度の低下 が緩やかで，圧縮勒性が向上した。Table1 より普通コンクリートの 圧縮強度は $\sigma_{\mathrm{B}}=33.3 \sim 51.9 \mathrm{~N} / \mathrm{mm}^{2}$ に対してFRC は $\sigma_{\mathrm{B}}=31.8 \sim 45.4 \mathrm{~N} / \mathrm{mm}^{2}$ で, 普通コンクリートに繊維を混入した FRCの圧縮強度は, 普通コ ンクリートに比べ 1 割程度低下したが，この傾向は既往の FRC に関 する研究 ${ }^{281,29)}$ と同様の結果である。

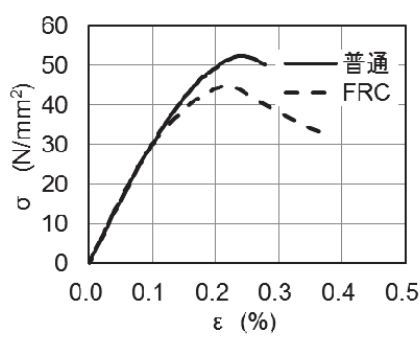

(a) Compressive test

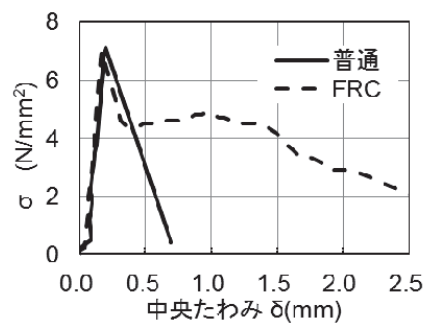

(b) Bending test
Fig. 3 Test results of $\mathrm{FRC}$ 


\section{b) 曲げひび割れ強度}

Fig.3(b)に曲げ試験から得られた曲げ強度一スパン中央たわみ関 係の一例を示す。普通コンクリートは, 応力が $\sigma=7 \mathrm{~N} / \mathrm{mm}^{2}$ 程度で曲 げひび割れ発生後, 急激に強度が低下した。それに対し FRC は, 普 通コンクリートと同様に $\sigma=7 \mathrm{~N} / \mathrm{mm}^{2}$ 程度で曲げひび割れが発生した 後, $\sigma=4 \sim 5 \mathrm{~N} / \mathrm{mm}^{2}$ に強度が一旦低下したが, その後も強度を維持し た。このように FRC は, 曲げひび割れ強度は普通コンクリートとほ ぼ同等であるが，曲げ勒性が向上することがわかる。

Fig.4 に圧縮強度と曲げ強度の関係 $\left(\sqrt{\sigma_{\mathrm{B}}}-\sigma_{\mathrm{b}}\right)$ を, 本実験結果 の他, 文献 28) 30)の材料試験結果も併せて示す。図中の実線は式 (1)にお゙けるコンクリートの曲げ強度 $\sigma_{\mathrm{b}}=0.56 \sqrt{\sigma_{\mathrm{B}}}$ を表している。全 てのデータが式(1)の曲げ強度を上回っていることがわかる。実験值 から求めたコンクリートの曲げ強度 $\sigma_{\mathrm{b}}$ は, 普通コンクリートが平均 $0.79 \sqrt{\sigma_{\mathrm{B}}}, \mathrm{FRC}$ が $0.97 \sqrt{\sigma_{\mathrm{B}}}$ であり, FRC の曲げ強度が普通コンク リートより高い。しかしながら FRC の圧縮強度が普通コンクリート より 1 割程度低下寸ることを考慮すれば，ひび割れ強度はほぼ同等 と言える。以上のように, FRC の繊維はひび割れ発生後の勒性向上 に効果があるが曲げ強度上昇の効果は認められず, 曲げ強度は $\sigma_{b}=$ $0.56 \sqrt{\sigma_{\mathrm{B}}}$ により評価できるものと考えられる。

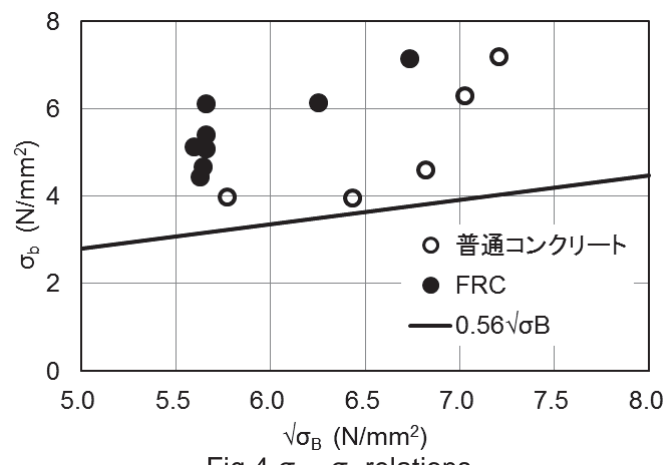

Fig. $4 \sigma_{B}-\sigma_{b}$ relations.

\section{c) 割裂引張強度}

通常のコンクリートの割裂引張試験では, 最大強度に達すると試 験体が二つに分断され, 強度を喪失する。一方 FRC では, 最大強度 に達すると, 中央にひび割れが発生し強度が低下するが, 䋊維によ り試験体が 2 つに分離することなく僅かに強度を維持していた。こ のことは, 圧縮試験, 曲げ試験と同様に繊維による引張勒性を向上 させる効果といえる。

割裂引張強度は, Table1 に示すように普通コンクリートと FRCの 比較では, ほぼ同等であった。

Fig.5に圧縮強度と割裂引張強度の関係 $\left(\sqrt{\sigma_{\mathrm{B}}}-\sigma_{\mathrm{T}} \mathrm{⿵}^{\mathrm{x}}\right.$ 係 $)$ を, Fig.4
と同様に本実験データと文献28)～30)の結果を併せて示す。図中の 実線は式(2)におけるコンクリートの引張強度 $\sigma_{\top}=0.313 \sqrt{\sigma_{\mathrm{B}}}$ を表し ている。全てのデータが式(2)を上回っていることがわかる。実験か ら求めたコンクリートの引張強度 $\sigma$ 个中, 普通コンクリートが 0.44 $\sqrt{\sigma_{\mathrm{B}}}, \mathrm{FRCが} 0.50 \sqrt{\sigma_{\mathrm{B}}}$ であり, FRCの引張強度が普通コンクリー 卜より僅かであるが高い結果となっていた。これらの結果から， RC の引張強度は $\sigma_{\mathrm{T}}=0.313 \sqrt{\sigma_{\mathrm{B}}}$ により評価できるものと考えられる。

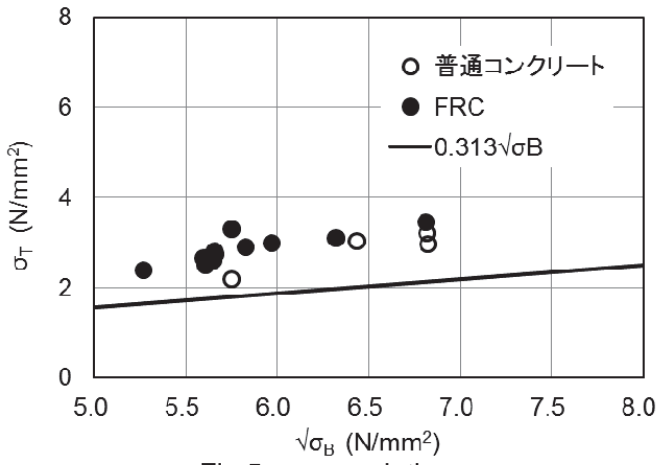

Fig.5 $\sigma_{B}-\sigma_{T}$ relations.

\subsection{CES 部材のひび割れ強度}

前節の検討により, FRC の曲げひび割れ強度は $\sigma_{\mathrm{b}}=0.56 \sqrt{\sigma_{\mathrm{B}}}$, 割 裂引張強度は $\sigma_{\mathrm{T}}=0.313 \sqrt{\sigma_{\mathrm{B}}}$ でほぼ評価できることが分かった。こ れらのことから，文献 4)～6)，22），23)の実験結果に基づき，CES 部 材の曲げひび割れ強度とせん断ひび割れ強度を検証する。

CES 柱および梁のひび割れ強度の一覧を Table2 に, CES 部材のひ び割れ強度の実験值と計算値の関係を Fig.6 に示す。

Fig.6(a)より, 実験における曲げひび割れモーメントは, CES 柱の 実験值と計算值との比が 1.28 , CES 梁の実験值と計算值との比が 1.07 であり, 式(1)による曲げひび割れモーメントを概ね上回ってい る。同様に Fig.6(b)より, せん断ひび割れ強度の実験值と計算值の 関係は, CES 柱の実験值と計算值との比が 1.09, CES 梁の実験值と

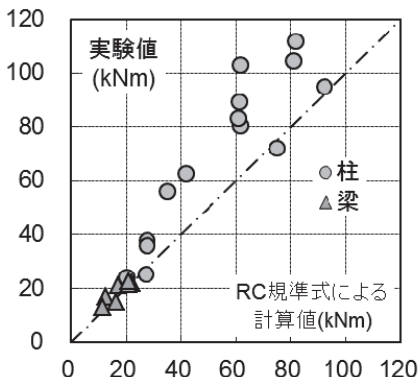

(a) Bending crack

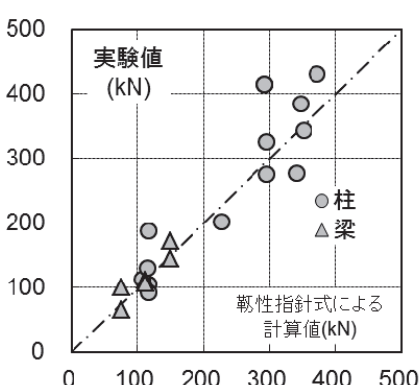

(b) Shear crack Fig. 6 Crack strength of CES members

Table2 Crack strength of columns ${ }^{4) \sim 6)}$ and beams $\left.{ }^{22,}, 23\right)$

\begin{tabular}{|c|c|c|c|c|c|c|c|c|c|c|c|c|c|c|c|c|c|c|c|c|c|c|}
\hline \multicolumn{2}{|c|}{ 試験体名 } & A2 & B1 & B2 & B3 & B3L & B $3 \mathrm{H}$ & C2 & D2 & D3 & R1 & R2 & R3 & R4 & R5 & $\begin{array}{c}\mathrm{SH}-2 \\
00\end{array}$ & $\begin{array}{c}\mathrm{SH}-3 \\
00\end{array}$ & $\begin{array}{c}\mathrm{SH}-4 \\
00\end{array}$ & \begin{tabular}{|l|}
$\mathrm{DH}-$ \\
200 \\
\end{tabular} & \begin{tabular}{|l|} 
DH- \\
300
\end{tabular} & $\begin{array}{l}\text { DH- } \\
400\end{array}$ & No.3 \\
\hline コンクリート強度 & $\sigma_{B}\left(\mathrm{~N} / \mathrm{mm}^{2}\right)$ & 43.9 & 43.2 & 43.9 & 44.7 & 43.6 & 45.0 & 42.7 & 42.2 & 42.4 & 33.0 & 26.9 & 32.5 & $\mid 33.0$ & 33.0 & 31.9 & 31.9 & 31.9 & 31.7 & 31.7 & 45.3 & 45.3 \\
\hline 作用軸力 & $\mathrm{N}(\mathrm{kN})$ & 800 & 400 & 800 & 1200 & 1130 & 1365 & \begin{tabular}{|l|l|}
800 \\
\end{tabular} & 800 & 1200 & 50 & 50 & 50 & 50 & 50 & 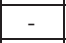 & 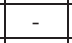 & - & \begin{tabular}{|l|}
- \\
\end{tabular} & - & - & \\
\hline 軸応力度 & $\sigma_{0}=\mathrm{N} / \mathrm{bD}\left(\mathrm{N} / \mathrm{mm}^{2}\right)$ & 8.89 & 4.44 & 8.89 & 13.3 & 12.6 & 15.2 & \begin{tabular}{|l|l|}
8.89 \\
\end{tabular} & 8.89 & 13.3 & \begin{tabular}{|l|l|}
0.63 \\
\end{tabular} & 0.63 & 0.63 & \begin{tabular}{|l|l|}
0.63 \\
\end{tabular} & 0.63 & - & 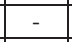 & & - & - & - & \\
\hline & & 3.71 & 3.68 & 3.71 & 3.74 & 3.70 & 3.76 & \begin{tabular}{|l|l}
3.66 \\
\end{tabular} & 3.64 & 3.65 & 3.22 & 2.90 & 3.19 & 3.22 & 3.22 & 3.16 & 3.16 & 3.16 & 3.15 & 3.15 & 3.77 & 3.77 \\
\hline 曲げひひ & & 61.4 & 42.0 & 61.4 & 81.8 & 74.9 & 92.3 & 61.1 & 60.9 & 80.9 & 27.8 & 20.3 & 27.4 & 35.0 & 27.8 & 12.6 & 17.3 & 22.0 & 11.6 & 16.3 & 20.9 & 20.9 \\
\hline 曲げひび割れ実験値 & $\cdot \mathrm{m})$ & 80.4 & \begin{tabular}{|l|}
62.6 \\
\end{tabular} & 103 & 112 & 72.0 & 95.0 & \begin{tabular}{|l|l}
89.1 \\
\end{tabular} & 83.3 & 104 & 38.0 & 24.2 & 25.1 & 56.0 & 35.8 & 16.8 & 21.0 & 21.8 & 13.2 & 15.1 & 22.5 & 22.5 \\
\hline コンクリート引張強度 & & 2.19 & 2.17 & 2.19 & 2.21 & 2.18 & 2.21 & \begin{tabular}{|l|l|}
2.16 \\
\end{tabular} & 2.14 & 2.15 & \begin{tabular}{|l|l|}
1.90 \\
\end{tabular} & 1.71 & 1.88 & 1.90 & 1.90 & 1.86 & 1.86 & 1.86 & 1.86 & 1.86 & 1.86 & \\
\hline せん断ひび割れ強度 & & 295 & 227 & 295 & 351 & 340 & 372 & \begin{tabular}{|l|l}
293 \\
\end{tabular} & 292 & 346 & 117 & 107 & 116 & 117 & 117 & 75 & 112 & $\mid 149$ & 74 & $\mid 111$ & 149 & \\
\hline せん断ひび割れ実験値 & $\mathrm{eV}_{\mathrm{c}}(\mathrm{kN})$ & 275 & 202 & 326 & 343 & 277 & 431 & 415 & 415 & 385 & 106 & 113 & 130 & 93.3 & 188 & 65 & 112 & 172 & 101 & 107 & 145 & \\
\hline
\end{tabular}


計算值との比が 1.05 であり，実験值と勒性指針式との対応は良い。 以上のことから，CES 柱および梁の曲げひび割れ強度は，式(1) により実験值のほぼ下限を, せん断ひび割れ強度は, 式(2)により実 験值を平均的に評価できるものと考えられる。

\section{FRC の曲げ圧縮性能の検討}

\section{1 偏心圧縮実験の概要}

FRCの曲げ圧縮性状を明らかにするため, 偏心圧縮実験を行った。 試験体形状は，2 章の曲げ試験と同一とし， b $\times D=100 \times 100 \mathrm{~mm}$ の 正方形断面で長さ $\mathrm{L}=400 \mathrm{~mm}$ である。試験体数は 8 体で, 設計基準 強度 $\mathrm{F}_{\mathrm{c}}=27 \mathrm{~N} / \mathrm{mm}^{2}$ の普通コンクリートにビニロンファイバー （RF4000）を体積混入率で $1.0 \%$ 混入して製作した。

実験方法をFig.7 に示す。実験は $2000 \mathrm{kN}$ 万能試験機を用い, 試験 体上下にかまぼこ型球座を用いたピン支持として実施した。試験体 一覧を Table5 に示寸。載荷方法は, 中心圧縮実験, 断面主軸方向に 偏心圧縮した 1 軸偏心圧縮実験, 主軸に対して 45 度方向に偏心圧縮 した 2 軸偏心圧縮実験の 3 種類とした。

偏心距離 e は試験体断面図心位置からとし, 1 軸偏心圧縮実験で は $\mathrm{e}=5 \mathrm{~mm} \sim 25 \mathrm{~mm}$ で, $5 \mathrm{~mm}$ ピッチで変化させた。2 軸偏心圧縮実 験では, 主軸の $X, Y$ 方向にそれぞれ偏心距離を $e_{x}=e_{y}=10 \mathrm{~mm}, 15 \mathrm{~mm}$ の 2 種類とした。計測は，1軸偏心圧縮実験では試験体長さ中央部 に貼り付けた 2 枚のひずみゲージと同一面に取り付けたパイ型変位 計（検長 $200 \mathrm{~mm}$ ）から試験体の軸ひずみならびに曲率を求めた。2 軸偏心圧縮実験では, 試験体側面の長さ中央部にそれぞれ 4 枚のひ ずみゲージを貼り付け, 試験体の軸ひずみならびに曲率を測定した。

\section{2 実験結果}

実験結果の一覧を Table3 に, 軸方向応力一軸ひずみ関係をFig.8 に示す。図の縦軸は荷重 N を試験体の断面積で除した応力度で, 横 軸は試験体の図心位置における平均軸ひずみである。図中には弾性 剛性 $E$ も示しているが, いずれの試験体も初期剛性はほぼ一致して いる。また, 偏心距離が大きい試験体ほど応力度が低い段階で剛性 低下が生じ, 低い応力度で最大值に達している。

Fig.9 に曲げモーメントー曲率関係を示す。図の縦軸 M は, M =N ・ e として求めた值であり, 横軸は 1 軸および 2 軸偏心圧縮実験とも に断面主軸方向の曲率を示している。いずれの試験体においても, 実験の初期剛性は, 計算弾性剛性 EI とほぼ一致している。一方で,

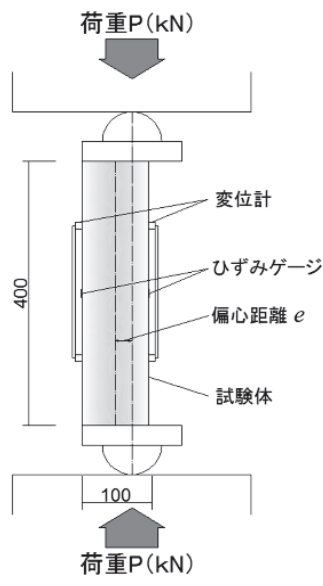

(a) Uniaxial bending

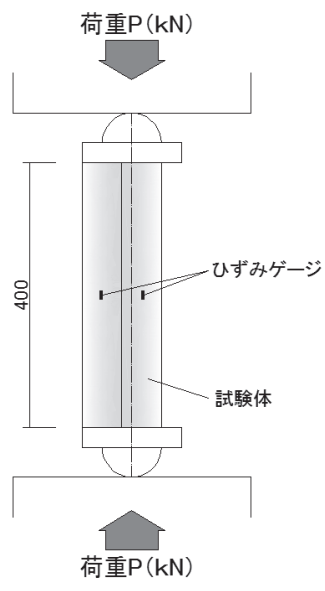

(b) Biaxial bending
偏心距離 e が大きくなるほど, モーメントが高くなる傾向となった。 偏心距離が等しい 1 軸と 2 軸偏心圧縮実験を比較した場合, 曲げモ 一メントの最大值は 2 軸偏心が小さくなっている。

本試験体では偏心距離が，1 軸偏心では $\mathrm{e} \leqq 15 \mathrm{~mm} ， 2$ 軸偏心では $e_{x}, e_{y} \leqq 10 m m$ が断面の核の内側になる。Table3 には最大荷重時にお ける断面内のひずみを示しているが, 実験では 1 軸偏心が $e=5 \mathrm{~mm}$, 2 軸偏心が $e_{x}, e_{y}=10 m m$ の場合のみ断面内のひずみが圧縮側となった。 他の試験体では，中立軸は断面内にあり，偏心距離が大きくなるほ ど圧縮縁から中立軸までの距離が短くなっている。ひずみ測定值よ り最大荷重時の圧縮側の縁ひずみを求めると, 1 軸, 2 軸偏心圧縮実 験のいずれの試験体も $\varepsilon_{\mathrm{c}} \doteqdot 0.003 \sim 0.004$ であった。

\subsection{FRC の曲げ圧縮耐力}

\section{(a) 1 軸偏心実験}

軸方向力と曲げモーメントを受ける CES 柱の耐力は, これまでの 研究では SRC 規準に基づく一般化累加耐力式により評価できると されている。SRC 規準では，短期許容曲げ耐力ならびに終局曲げ耐

Table3 Specimens and test results

\begin{tabular}{|c|c|c|c|c|c|c|c|}
\hline & $\begin{array}{c}\text { 偏心距離 } \\
\mathrm{e} \\
(\mathrm{mm})\end{array}$ & $\begin{array}{c}\text { 最大荷重 } \\
N \\
(\mathrm{kN})\end{array}$ & $\begin{array}{c}\text { 最大応力 } \\
\sigma \\
\left(\mathrm{N} / \mathrm{mm}^{2}\right)\end{array}$ & $\begin{array}{c}\text { モーメント } \\
M \\
(\mathrm{kN} \cdot \mathrm{m})\end{array}$ & $\begin{array}{c}\text { 中立軸 } \\
(\mathrm{mm})\end{array}$ & $\begin{array}{c}\text { ひずみ } \\
\varepsilon_{1} \\
\left(\times 10^{-6}\right) \\
\end{array}$ & $\begin{array}{c}\text { ひずみ } \\
\varepsilon_{2} \\
\left(\times 10^{-6}\right) \\
\end{array}$ \\
\hline 中心圧縮 & $\mathrm{e}=0$ & 397 & 39.7 & - & & \multicolumn{2}{|c|}{2086} \\
\hline \multirow{5}{*}{1 軸偏心 } & $e=5$ & 335 & 33.5 & 1.67 & 107.0 & 3131 & 205 \\
\hline & $e=10$ & 312 & 31.2 & 3.12 & 85.3 & 3578 & -614 \\
\hline & $e=15$ & 250 & 25.0 & 3.75 & 79.5 & 3849 & -995 \\
\hline & $e=20$ & 235 & 23.5 & 4.71 & 66.7 & 4163 & -2077 \\
\hline & $e=25$ & 219 & 21.9 & 5.48 & 58.7 & 4059 & -2859 \\
\hline \multirow{4}{*}{2 軸偏心 } & \multirow{2}{*}{$e_{x}=e_{y}=10$} & \multirow{2}{*}{267} & \multirow{2}{*}{26.7} & \multirow{2}{*}{$\begin{array}{c}3.77 \\
(2.67)\end{array}$} & 110.1 & 2224 & 205 \\
\hline & & & & & 108.5 & 1717 & 135 \\
\hline & \multirow{2}{*}{$e_{x}=e_{y}=15$} & \multirow{2}{*}{212} & \multirow{2}{*}{21.2} & \multirow{2}{*}{$\begin{array}{c}4.51 \\
(3.19)\end{array}$} & 94.3 & 2406 & -144 \\
\hline & & & & & 88.7 & 2258 & -288 \\
\hline
\end{tabular}

$※: M=N \cdot e, M=N \cdot \sqrt{ } 2 e_{x}=N \cdot \sqrt{2} e_{y}, \varepsilon_{1}:$ は圧縮側, $\varepsilon_{2}$ は引張側ひずみで, 圧縮を正, 引張を負として示している。

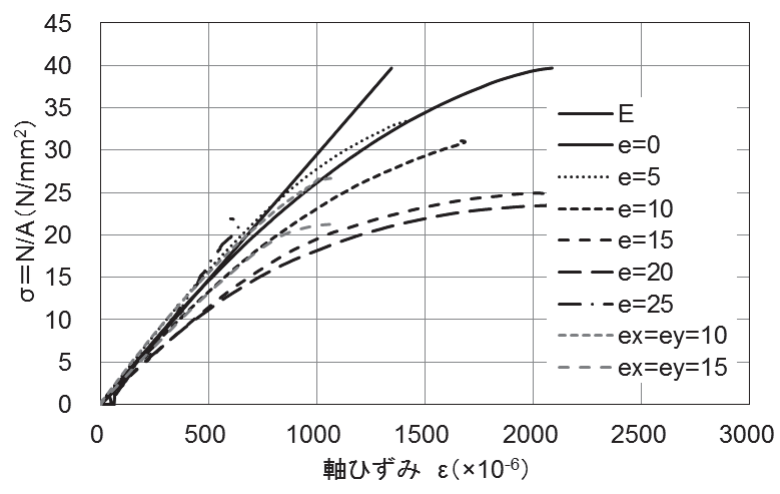

Fig. 8 Axial stress - strain relationships

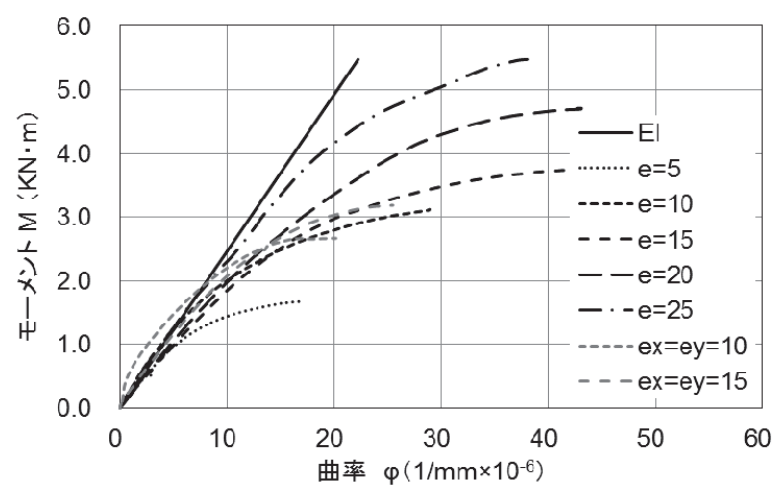

Fig. 9 Moment - curvature relationships 
力が Fig.10(a)に示すようなストレスブロックを仮定して求められる。 この時の短期許容圧縮而力 $\mathrm{N}_{\mathrm{s}}$ および短期許容曲げモーメント $\mathrm{M}_{\mathrm{s}}$ は, 次式ように表される。

$$
N_{s}=f_{c} \cdot \frac{b \cdot x_{n}}{2}, \quad M_{S}=f_{c} \cdot \frac{b \cdot x_{n}\left(3 D-2 x_{n}\right)}{12}
$$

ここで, $f_{c}: F R C$ の短期許容応力度 $\left(=(2 / 3) \sigma_{B}\right), x_{n}$ : 圧縮縁から中 立軸までの距離である。なお中心圧縮の場合は, $N_{s}=f_{c} \cdot b \cdot D, M_{s}=0$ である。

同様に, 終局圧縮耐力 $\mathrm{N}_{\mathrm{u}}$ および終局曲げモーメント $\mathrm{M}_{\mathrm{u}}$ は, 次式 のように表される。

$$
N_{u}={ }_{c} r_{U} \cdot \sigma_{B} \cdot b \cdot x_{n}, \quad M_{u}={ }_{c} r_{U} \cdot \sigma_{B} \cdot \frac{b \cdot x_{n}\left(D-x_{n}\right)}{2}
$$

ここで, ${ }{ }$ r $u$ : 鉄骨比に応じて定まるコンクリート強度の低減係数 ${ }_{C} r_{u}=0.85-2.5_{s} P_{c},{ }_{s} P_{c}$ : 圧縮側鉄骨比) である。なお中心圧縮の場合 は， $x_{n}=D$ とすることで求められる。

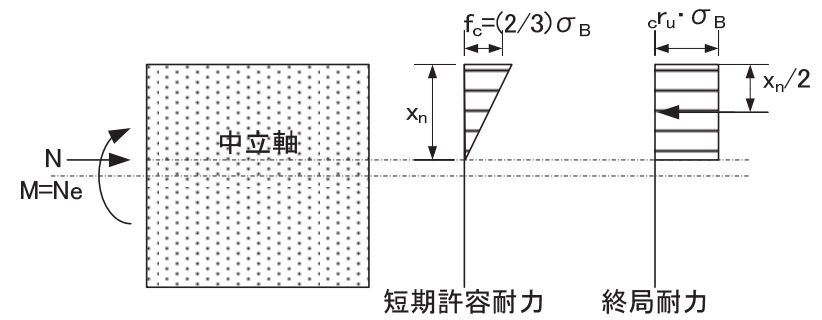

(a) Uniaxial bending

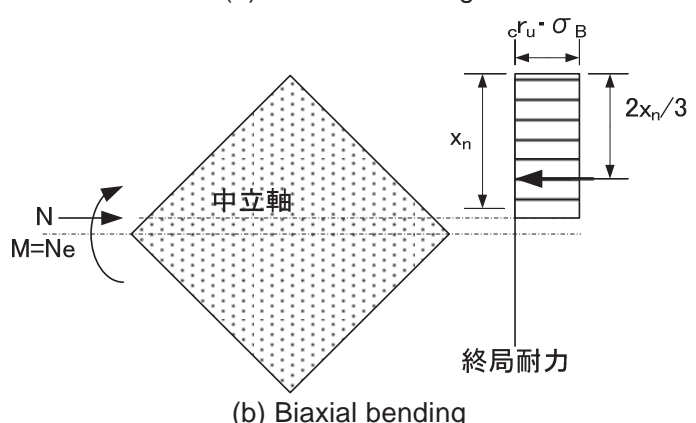

Fig.10 Assumed stress blocks

Fig.11にSRC 規準による各耐力の計算值に実験結果をプロットし て示す。本実験はFRCのみの試験体であるため, ${ }^{2} r_{U}=0.85$ となるが, 参考のため ${ }^{\prime} \mathrm{r} u=1.0$ とした計算結果も併せて示している。また, 偏 心圧縮試験体の短期許容而力は, 中心圧縮実験より得られた応力ー ひずみ関係を基に, 圧縮応力度が(2/3) $\sigma_{\mathrm{B}}$ に達したときのひずみを求 め, 圧縮縁ひずみがその值に達したときの荷重から求めている。短
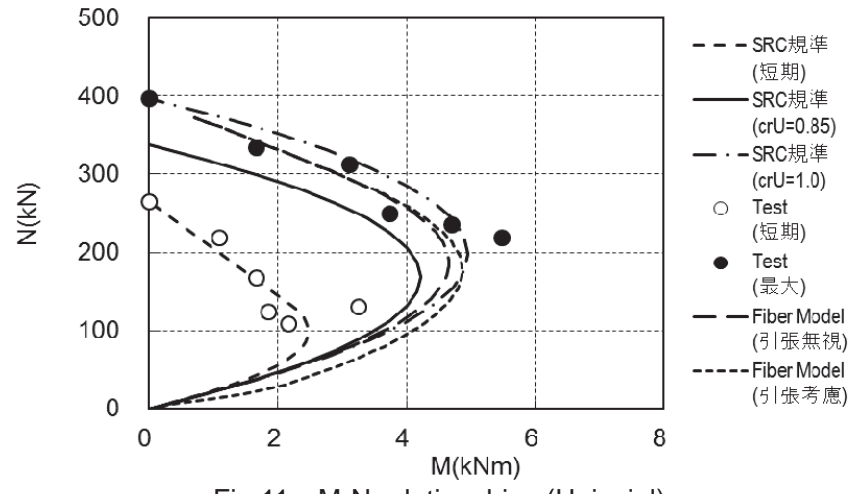

Fig.11 M-N relationships (Uniaxial)
期許容耐力に関しては, 実験結果に多少のばらつきはあるものの, SRC 規準との対応は良好である。

最大耐力に関しては, 実験結果は ${ }^{2} r_{U}=0.85$ として求めた耐力を全 ての試験体で上回っている。一方で ${ } r_{U}=1.0$ とした計算結果に対し ては, 偏心距離が最も大きい $\mathrm{e}=25 \mathrm{~mm}$ の試験体では計算值を上回っ ているものの, 他の試験体では若干下回った。以上のことから, FRC 部分の曲げ耐力は，SRC 規準に準じた被覆 RC 部と同様の評価方法 により安全側に評価できることがわかった。

\section{(b) 2 軸偏心実験}

1 軸偏心実験と同様に，2 軸偏心を受ける FRC 部材の曲げ圧縮耐 力の検討を行った。なお 2 軸曲げを受ける FRC の短期許容耐力 $M_{s}$ は, SRC 規準によれば 1 軸偏心の短期許容曲げ耐力の $1 / \sqrt{2}$ になる。 また終局圧縮耐力 $N_{u}$ および終局曲げモーメント $M_{u}$ は, Fig.10(b)の ように仮定すれば次式のように表される。

$\left(0 \leqq x_{n} \leqq D / \sqrt{2}\right)$

$$
\begin{aligned}
& N_{u}={ }_{c} r_{U} \cdot \sigma_{B} \cdot x_{n}{ }^{2}, \quad M_{u}={ }_{c} r_{U} \cdot \sigma_{B} \cdot x_{n}{ }^{2}\left(\frac{D}{\sqrt{2}}-\frac{2 x_{n}}{3}\right) \cdot \cdot(5) \\
& \left(D / \sqrt{2} \leqq x_{n} \leqq 2 D / \sqrt{2}\right) \\
& N_{u}={ }_{c} r_{U} \cdot \sigma_{B}\left\{D^{2}-\left(\frac{2 D}{\sqrt{2}}-x_{n}\right)^{2}\right\}, \\
& M_{u}={ }_{c} r_{U} \cdot \sigma_{B}\left(\frac{2 D}{\sqrt{2}}-x_{n}\right)\left(2 x_{n}-\frac{D}{\sqrt{2}}\right) \cdot \frac{1}{3} \ldots \ldots \ldots \ldots \ldots \ldots(6)
\end{aligned}
$$

Fig.12 にSRC 規準による各耐力の計算值に実験結果をプロットし て示す。図の横軸は曲げ方向（45 度方向）の曲げモーメントを，終 局耐力の計算值は, ${ }^{r} r_{U}=0.85$ と ${ } r_{U}=1.0$ とした計算結果を示している。 短期許容耐力に関しては，SRC 規準式を若干上回り，実験結果と計 算值との対応は良好である。最大耐力に関しては，実験結果は全て の試験体で ${ }^{r}{ }_{u}=0.85$ として求めた耐力と ${ } r_{u}=1.0$ とした耐力の間にプ ロットされており，2 軸曲げを受ける場合においても，FRC 部分の 耐力は SRC 規準に基づき算定して良いものと判断される。

\section{4 断面曲げ解析による FRC の終局耐力の検討}

更に FRC の耐力を調べる目的で, 平面保持の仮定による断面曲げ 解析（ファイバーモデル）により比較を行った。断面曲げ解析によ る FRC の応力ーひずみ関係は, 文献 7)で FRC を対象に提案された モデル (Fig.13 参照) を用いた。このモデルは圧縮側コンクリート は孫・崎野モデルを基に提案されたもので, 引張側は FRC の引張特 性を考慮したものである。なお，断面曲げ解析はFig.14に示すよう
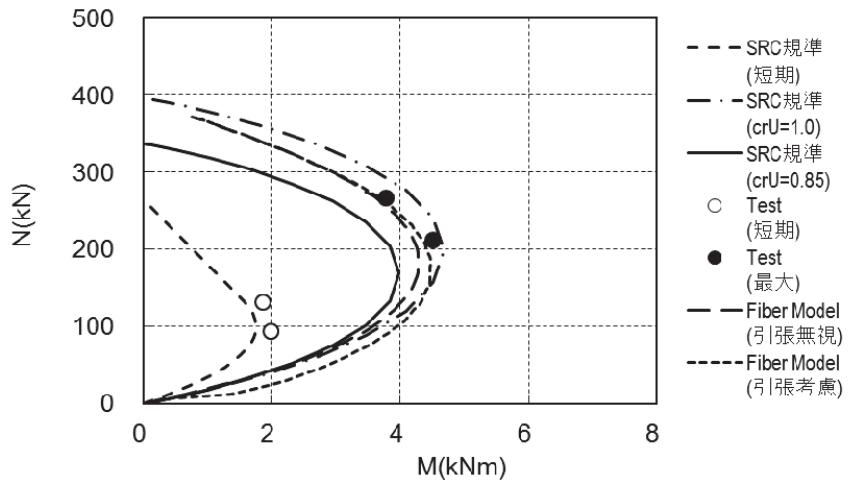

Fig.12 M-N relationships (Biaxial) 
に曲げ方向に対して断面を 20 分割している。また耐力曲線は, 圧縮 縁ひずみ $\varepsilon_{\mathrm{cu}}$ が $0.3 \%$ の時の耐力で評価している。

断面曲げ解析による結果と実験結果をFig.11 およびFig.12に示す。 FRCの引張強度を無視した場合と考慮した場合の 2 ケースについて 示している。FRCの引張強度を無視した場合の断面曲げ解析の結果 は, SRC 規準における ${ } r_{u}=0.85$ と ${ } r_{u}=1.0$ の耐力曲線の間に位置し ており, 実験結果との対応はSRC 規準に比べ良い。引張強度を考慮 した場合の断面曲げ解析の結果は, 軸力が高い範囲では引張強度を 無視した場合の断面曲げ解析の結果と一致するが, 軸力が低い領域 では曲げ耐力が大きく評価される。よって, 偏心距離が大きい（軸 力が低い）場合には，FRCの引張強度を考慮したほうが実験との対 応が良くなるものと考えられる。

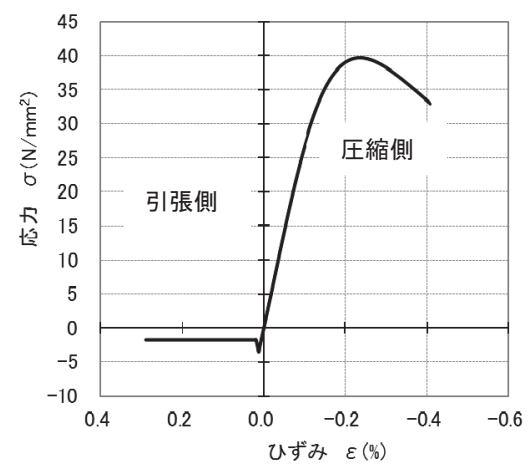

Fig.13 Stress-strain relationships of FRC

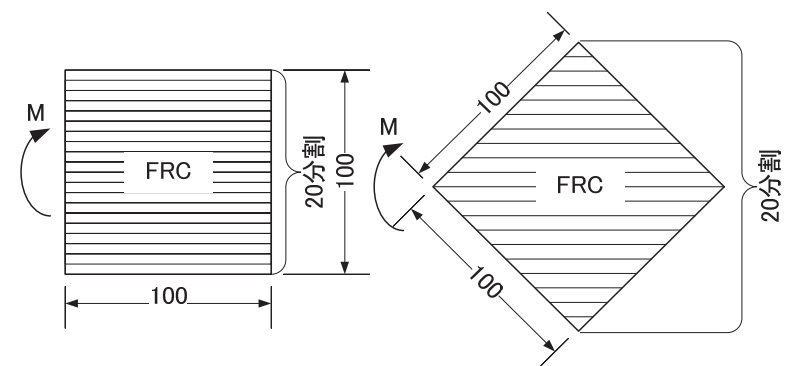

Fig.14 Analytical models

\section{FRC による座屈補剛効果の検討}

\section{1 実験概要}

文献 22)では, コンクリートの種類（再生骨材コンクリート, 普 通コンクリートおよび FRC）を変数とした SC 短柱の中心圧縮実験 により，構造性能の検討が行われている。その研究によれば，コン クリートの種類に関わらず圧縮強度は同等であるが, FRC では最大 強度以降の耐力低下が緩やかになり, またコンクリートの剥落が防 止されることが明らかになっている。しかしながら内蔵鉄骨の幅厚 比が小さく, また 1 種類であることから, 被覆 FRC による内蔵鉄骨 の局部座屈に対する補剛効果を検証するため, 幅厚比を実験変数と した中心圧縮実験を行った。試験体の一覧をTable6, 試験体形状を Fig.15 に示す。試験体は, 幅厚比の異なる 3 種類の鉄骨試験体が 3 体，その鉄骨をFRCにより被覆したCES 試験体が 3 体，FRCのみ とした試験体 1 体の合計 7 体である。

試験体の鉄骨断面は日本建築学会「鋼構造計算規準」 ${ }^{31)}$ (以下, S 規準) およびSRC 規準に基づき, N 0.1 は両規準を満足, N 0.2 は SRC 規準のみ満足, N 0.3 は両規準を満足しない幅厚比を設定した。なお, $F R C$ 断面は $b \times D=150 \times 150 \mathrm{~mm}$ の正方形断面とし, 試験体高さは
300mm（=2D） とした。またコンクリートの打設は，試験体上端よ り縦打ちで行い，打設面は石膏を用いて平滑に仕上げた。

コンクリートの設計基準強度は $\mathrm{F}_{\mathrm{c}}=27 \mathrm{~N} / \mathrm{mm}^{2}$ とし, FRC はビニロ ンファイバー（RF4000）を体積混入率で $1.0 \%$ 混入して製作した。

Table5 に使用した鋼材の材料試験結果を示す。内蔵鉄骨には SS400 材を用い，鋼材の引張試験片は 5 号試験片を用いた。

加力は Fig.16 に示すように, 試験体上下の拘束条件を上端球座, 下端固定として実施した。載荷は $2000 \mathrm{kN}$ 万能試験機による単調載 荷とし，試験体の平均軸方向ひず夕 $\varepsilon(=\delta / \mathrm{h}, \delta$ : 軸力方向変位， $\mathrm{h}$ ： 試験体高さ）が $5 \%$ に達するまで行うことを原則とした。

測定は，試験体 2 ヶ所に変位計を取り付け，上下加力用プレート 間の平均変位を測定した。また，H 形鋼および FRC にはひずみゲー ジを貼付し，各部のひずみを測定した。

BH- $100 \times 100 \times 3.2 \times 4.5$ BH- $100 \times 100 \times 2.3 \times 3.2$ BH- $150 \times 150 \times 2.3 \times 3.2$
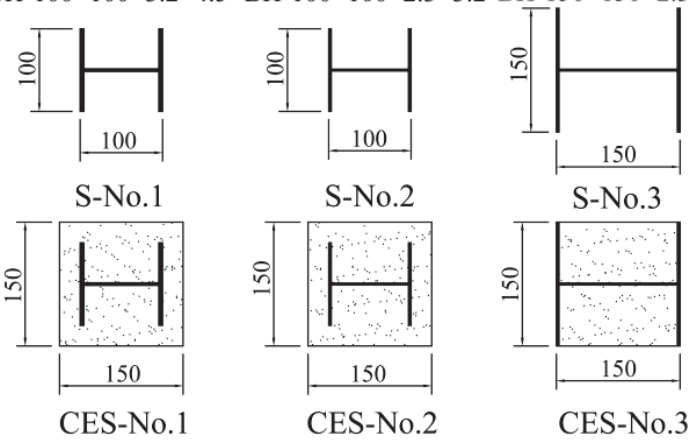

S-No.3

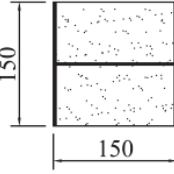

CES-No.3

Fig.15 Detail of specimens

Table4 Specimens and test results

\begin{tabular}{|c|c|c|c|c|}
\hline \multirow{2}{*}{ 試験体 } & 断面構成 & \multirow{2}{*}{$\begin{array}{c}\text { 計算耐力 } \\
N_{y}, N_{u}(k N)\end{array}$} & \multirow{2}{*}{$\begin{array}{l}\text { 最大耐力 } \\
\mathrm{N}_{\text {exp }}(\mathrm{kN})\end{array}$} & \multirow{2}{*}{$\begin{array}{l}\mathrm{N}_{\text {exp }} / \mathrm{N} \\
\mathrm{N}_{\exp } / \mathrm{N}\end{array}$} \\
\hline & 鉄骨 $(\mathrm{mm})$ & & & \\
\hline S-No.1 & BH-100×100×3.2×4.5 & 358 & 430 & 1.20 \\
\hline $\mathrm{S}-\mathrm{N} 0.2$ & $\mathrm{BH}-100 \times 100 \times 2.3 \times 3.2$ & 261 & 302 & 1.16 \\
\hline S-No.3 & $\mathrm{BH}-150 \times 150 \times 2.3 \times 3.2$ & 394 & 302 & 0.77 \\
\hline CES-N 0.1 & $\mathrm{BH}-100 \times 100 \times 3.2 \times 4.5$ & 870 & 1003 & 1.15 \\
\hline CES-N 0.2 & $\mathrm{BH}-100 \times 100 \times 2.3 \times 3.2$ & 801 & 908 & 1.13 \\
\hline CES-N 0.3 & $\mathrm{BH}-150 \times 150 \times 2.3 \times 3.2$ & 900 & 1014 & 1.13 \\
\hline FRC & - & - & 586 & - \\
\hline
\end{tabular}

Table5 Material properties of steel

\begin{tabular}{c||c|c|c|c|c}
\hline 種類 & $\begin{array}{c}\text { 板厚 } \\
\mathrm{t} \\
(\mathrm{mm})\end{array}$ & $\begin{array}{c}\text { ヤング係数降伏強度 } \\
\mathrm{E}_{\mathrm{s}} \\
\left(\mathrm{kN} / \mathrm{mm}^{2}\right)\end{array}$ & $\begin{array}{c}\text { 引張強度 } \\
\left(\mathrm{N} / \mathrm{mm}^{y}\right)\end{array}$ & $\begin{array}{c}\sigma_{t} \\
\left(\mathrm{~N} / \mathrm{mm}^{2}\right)\end{array}$ & $\begin{array}{c}\text { 断伸び } \\
\varepsilon \\
(\%)\end{array}$ \\
\hline \hline $\mathrm{PL}-4.5$ & 4.55 & 195 & 290 & 442 & 40.4 \\
\hline $\mathrm{PL}-3.2$ & 3.18 & 197 & 307 & 425 & 38.2 \\
\hline $\mathrm{PL}-2.3$ & 2.28 & 200 & 307 & 362 & 35.8 \\
\hline
\end{tabular}

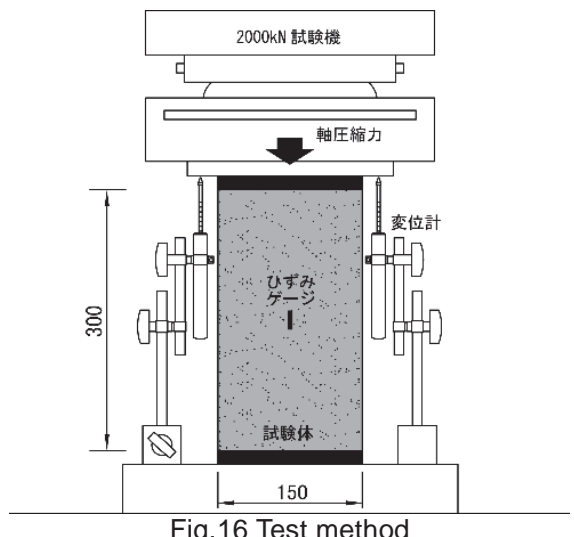

Fig.16 Test method 


\section{2 実験結果}

鉄骨試験体（S-N 0.1，2，3）の圧縮試験結果を Table4 および Fig.17 に, 最終破壊形状をFig.18 に示す。Table6 には材料試験による降伏 強度 $\sigma_{\mathrm{y}}$ を用いた降伏耐力 $\mathrm{N}_{\mathrm{y}}\left(=\sigma_{\mathrm{y}} \mathrm{A}_{\mathrm{s}}, \mathrm{A}_{\mathrm{s}}\right.$ : 鉄骨の断面積 $)$, 実験から 得られた最大耐力 $N_{\text {exp }}$ を示している。また, Fig.17 の縦軸は各試験 体の荷重 $\mathrm{N}$ を $\mathrm{N}_{\mathrm{y}}$ で基準化（N/Ny） して表している。

S-N 0.1, N 0.2 試験体では, 最大耐力 $\mathrm{N}_{\text {exp }}$ は降伏耐力 $\mathrm{N}_{\mathrm{y}}$ を上回り, 1.16〜1.20 倍の耐力を発揮し, その後フランジおよびウェブの局部 座屈が顕著になり耐力が低下した。最大耐力後の耐力低下は, S-N o.1 に比べ幅厚比の大きい S-N 0.2 の方が大きくなっている。一方, 最も 幅厚比が大きい S-N 0.3 では, 降伏耐力 $\mathrm{N}_{\mathrm{y}}$ に達する前の $0.77 \mathrm{~N}_{\mathrm{y}}$ 時に 局部座屈により耐力低下が生じた。

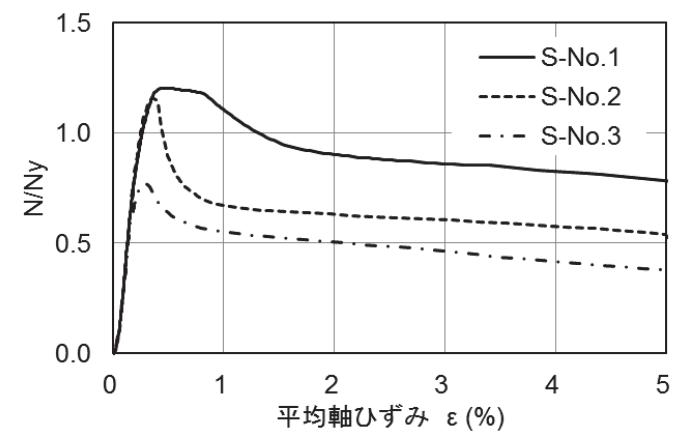

Fig.17 Test results of steel specimens

CES 試験体の圧縮試験結果を Table4 およびFig.19 に, 最終破壊形 状をFig.18 に示す。なお, Table4には, SRC 規準の式(7)による計算 圧縮耐力 $\mathrm{N}_{\mathrm{u}}$ を示している。また Fig.19 の縦軸は, 軸方向力 $\mathrm{N}$ を計 算圧縮耐力 $\mathrm{N}_{\mathrm{u}}$ で基隻化（N/N $\mathrm{N}_{\mathrm{u}}$ ) して表しており，Fig.18 は被覆 FRC の有無による鉄骨の破壊形状の差異を確認するため, CES 試験体の 被覆 FRC を実験終了後に斫り出した内蔵鉄骨の最終破壊形状も示 している。

$$
\mathrm{N}_{\mathrm{u}}=\mathrm{N}_{\mathrm{S}}+\mathrm{N}_{\mathrm{C}}=\sigma_{\mathrm{y}} \cdot \mathrm{A}_{\mathrm{S}}{ }{ }_{\mathrm{C}} \mathrm{r}_{\mathrm{U}} \cdot \sigma_{\mathrm{B}} \cdot \mathrm{A}
$$

ここで， $\mathrm{N}_{\mathrm{s}}, \mathrm{N}_{\mathrm{c}}$ : 鉄骨およびコンクリート部の終局圧縮耐力, $A_{\mathrm{s}}$ : 鉄骨の断面積, ${ }^{2} r_{U}$ ：コンクリート強度の低減係数 $\left(=0.85-2.5 \mathrm{~s} \mathrm{p}_{\mathrm{c}}\right.$, $\left.{ }_{s} \mathrm{p}_{c}=A_{s} / A\right), A$ : 合成部材の全断面積である。

CES 試験体では, 耐力低下と共にひび割れが発生したものの, 実 験終了までコンクリートの大きな剥落は認められなかった。Table4 より, いずれの試験体も計算耐力に対する最大耐力の比 $\left(\mathrm{N}_{\text {exp }} / \mathrm{N}_{\mathrm{u}}\right)$ に差がないことが分かる。内蔵鉄骨のみでは弾性座屈により降伏耐 力に達せず耐力低下したS-N 0.3 が，FRC で被覆したCES-No.3 にな ると計算耐力を上回ったことから, 最大耐力に関してはFRCによる 内蔵鉄骨の座屈補剛効果が認められたものと考えられる。また Fig.18 に示すように鉄骨試験体に比べ，CES 試験体の内蔵鉄骨では フランジおよびウェブの座屈波長が短くなる傾向があり，これも被 覆 FRC による効果と考えられる。しかしながら, 幅厚比が最も小さ いCES-N 0.1 に対してCES-N 0.2, N 0.3 と幅厚比が大きくなると, 最 大耐力後の耐力低下が大きくなっており, 幅厚比の違いによる変形 性能一の影響が認められた。

\subsection{FRC の補剛効果の検討}

Fig.20 は, CES 試験体の実験結果に同断面の鉄骨試験体，FRC 試 験体，ならびにそれらを足し合わせた結果（S+FRC）を重ね合わせ て示したものである。CES と S+FRC を比較すると, 最大耐力に関 してはN 0.1 では両者の差は認められないが，No.2 ではCES の耐力

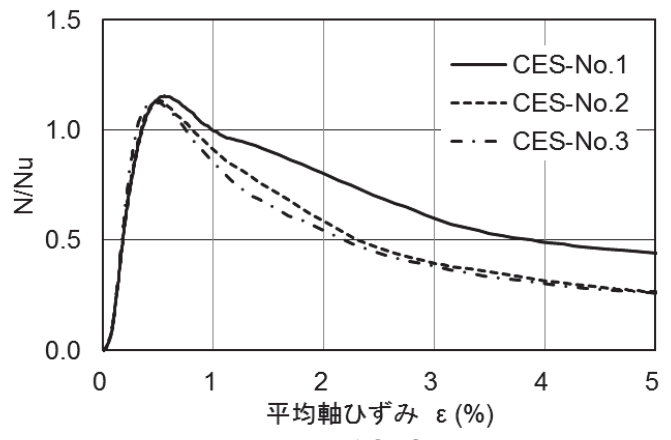

Fig.19 Test results of CES specimens

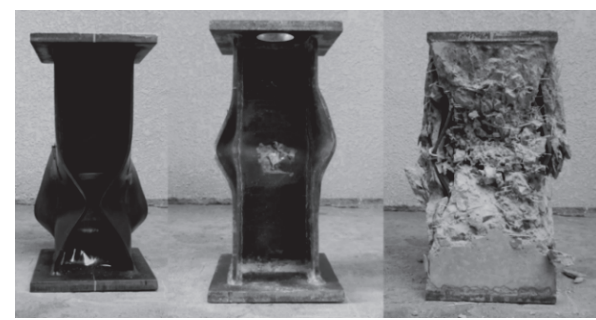

S-No.1

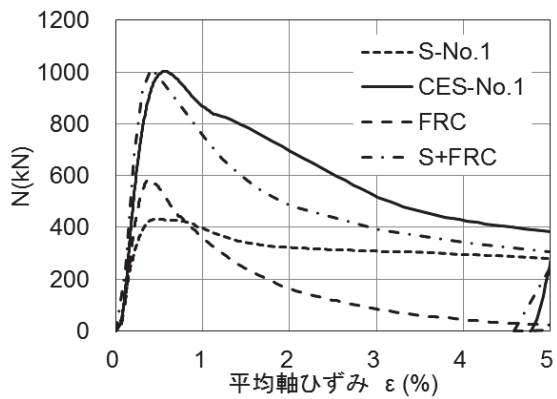

(a) No.1

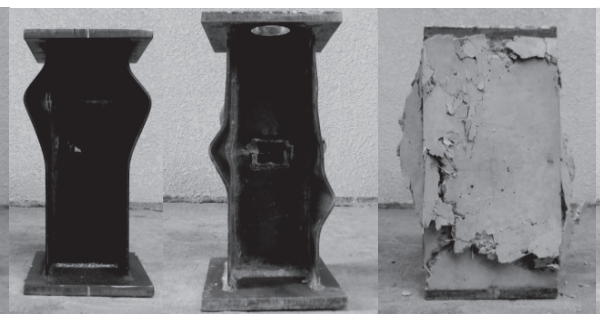

CES-No.2

Fig.18 Failure pattern of specimens

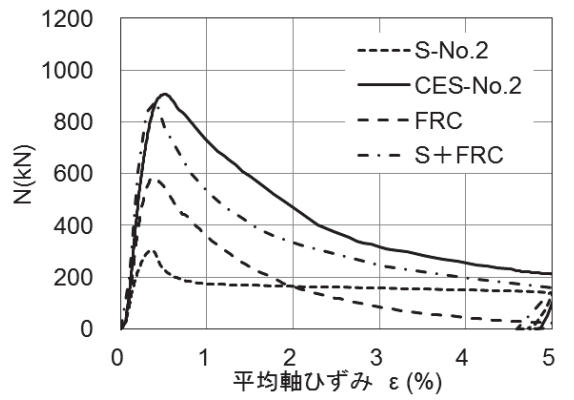

(b) No.2

Fig.20 Comparison between CES and S +FRC

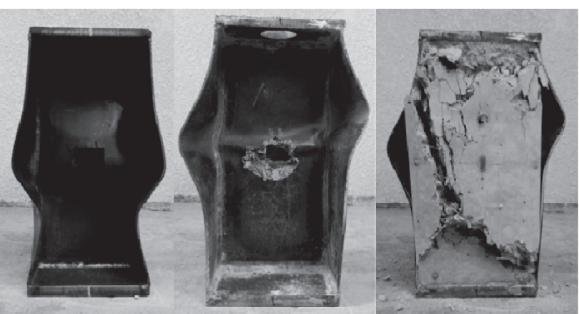

S-No.3

CES-No.3

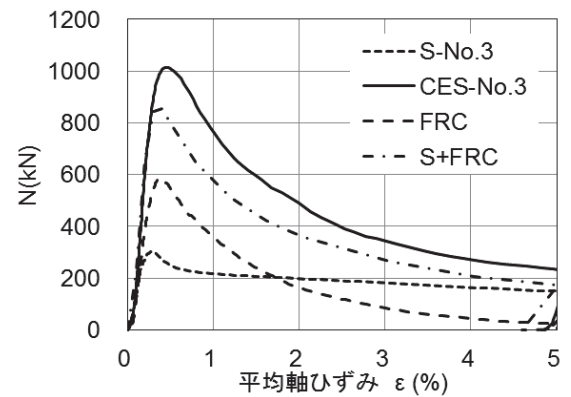

(c) No.3 
が若干高くなっている。更にN0.3では，S+FRC に対してCES の耐 力が明らかに上回っている。

SRC 構造における内蔵H 形鋼の幅厚比制限は, SRC 規準において, $\mathrm{S}$ 規準の制限值のフランジで 1.5 倍, ウェブで 2.0 倍と緩和されてい る。SRC 規準では, SRC 構造の幅厚比制限緩和の根拠として, フラ ンジ局部座屈に対しては，フランジとウェブに挟まれたコンクリー 卜により, 支持条件が変わることにより座屈強度が上昇すること, 一方ウェブに関しては, 両面が厚いコンクリートで押さえられてい るとされていおり，鉄筋の効果は考慮されていない。

CES 構造と SRC 構造の違いは鉄筋がないことと FRC を用いてい ることであり, Fig.20 に示すようにCES 構造に関しても SRC 構造 と同様の効果が認められ, SRC 構造と同様に幅厚比を緩和して良い ものと考えられる。

\section{5. まとめ}

CES 構造に適用される FRC の構造性能に着目した合成部材とし てのCES 構造の構造性能評価方法の検討を行った結果, 以下の知見 が得られた。

1) CES 構造に適用される FRC の曲げ強度, 割裂引張強度は普通コ ンクリートと同等である。但し補強繊維の効果により, 強度発揮 後の勒性は向上寸る。

2) 1)の結果から, CES 部材のひび割れ強度は, RC 部材のひび割れ 強度式が適用可能である。但し，(1)式は曲げひび割れ強度の下 限值を，(2)式はせん断ひび割れ強度を平均的に評価するものと 考えられる。

3）軸方向力と曲げモーメントを受ける FRC の短期許容耐力, 終局 耐力は，SRC 規準の仮定によるストレスブロックにより安全側 に評価できる。よって, 軸方向力と曲げモーメントを受けるCES 部材の耐力も SRC 規準に準じた一般化累加耐力式により評価で きる。更に断面曲げ解析によれば，耐力評価の精度が向上する。 4）鉄骨部材としては弾性座屈するような断面であっても, FRC で 被覆することにより内蔵鉄骨の座屈補剛効果が確認でき, 強度と 変形性能の向上が期待できる。よって CES 部材としての内蔵鉄 骨の幅厚比制限はSRC 部材と同様に緩和が可能である。

\section{謝辞}

本研究の一部は, 平成 26-28 年度文部科学省科学研究費補助金（基 盤研究(C), 課題番号 30612080, 代表者: 藤本利昭), 平成 26-29 年 度文部科学省科学研究費補助金（基盤研究(A), 課題番号 2624908, 代表者: 倉本洋) の助成を受けたものである。また本研究は, 日本 建築学会 鋼コンクリート合成構造運営委員会に設置された CES 構造性能評価指針検討小委員会（主查：倉本洋 大阪大学教授）の 活動の一環として実施したものである。ここに記して関係各位に謝 意を表します。

\section{参考文献}

1) 倉本洋 : 特集 /多様化するハイブリット構造の現状と今後の展開 $/ 4$. 新 技術の展開＼cjkstart建築分野・鉄骨コンクリート（CES）構造，コンクリート工 学, Vol.52, No.1, pp,115-120, 2014.1

2) 足立智弘，倉本洋，川崎清彦: 繊維補強コンクリートを用いた鉄骨コンク リート合成構造柱の構造性能に関する実験的研究, コンクリート工学年次 論文集，第 24 巻，第 2 号，pp.271-276， 2002.6

3) 足立智弘, 倉本洋, 川崎清彦, 柴山豊 : 高軸力を受ける繊維補強コンクリ
ートー鋼合成構造柱の構造性能に関する研究，コンクリート工学年次論文 集, 第 25 巻, 第 2 号, pp.289-294, 2003.6

4) 田口孝, 永田諭, 松井智哉, 倉本洋：H 型鉄骨を内蔵した CES 柱の構造 特性, コンクリート工学年次論文集第 28 巻, 第 2 号, pp.1273-1278, 2006.7

5) 溝淵博己, 松井智哉, 藤本利昭, 倉本洋 : 軸力比およびシアスパン比が異 なる H 型鉄骨内蔵 CES 柱の静的載荷実験, 第 8 回複合・合成構造の活用 に関するシンポジウム, CD-ROM, 2009.11

6) 松井智哉, 溝淵博己, 倉本洋: H 型鉄骨内蔵 CES 柱の構造実験と FEM 解 析, コンクリート工学年次論文集, 第 32 巻, 第 2 号, pp.1171- 1176, 2010.7

7) 藤本利昭, 倉本洋, 松井智哉, 小松博: 繊維補強コンクリートの材料特性 を考慮したCES 柱の終局耐力に関する考察, 日本建築学会構造系論文集, 第 75 巻, 第 658 号, pp.2231-2237, 2010.12

8) 石鈞吉, 牧元祐太, Juan J ose CASTRO, 松井智哉, 倉本洋 : H 型鉄骨内蔵 CES 柱の変形能力評価に関する研究, 日本建築学会構造系論文集, 第 77 巻, 第 682 号, pp.1977-1982, 2012.12

9) 石鈞吉, 倉本洋, 藤本利昭, 松井智哉, 牧元祐太 : H 型鉄骨内蔵 CES 柱 の復元力特性のモデル化に関する研究，日本建築学会構造系論文集，第 78 巻, 第 693 号, pp.2019-2026, 2013.11

10) 石川智康, 小山勉, 松井智哉, 倉本洋: CES 合成構造建築物における梁の 静的加力実験, コンクリート工学年次論文集, 第 37 巻, 第 2 号, pp.1057-1062 2015.7

11) 倉本洋, 松井智哉, 永田諭, 藤本利昭 : CES 合成構造システムにおける外 部柱梁接合部の構造性能, 日本建築学会構造系論文集, 第 73 巻, 第 624 号, pp.235-242, 2008.2

12) 松井智哉, 倉本洋 : 繰返し水平力を受ける CES 柱梁接合部の応力伝達機 構, 日本建築学会構造系論文集, 第 73 巻, 第 630 号, pp.1401-1407, 2008.8

13) 松井智哉, 倉本洋: CES 柱梁接合部の構造性能に及ぼす作用軸力の影響, 日本建築学会構造系論文集，第 76 巻，第 663 号，pp.1025-1031，2011.5

14) 岩瀬勝洋, 松井智哉, 倉本洋 : CES 内部柱梁接合部の構造性能, コンクリ - 卜工学年次論文集，第 30 巻，第 3 号, pp.1351-1356, 2008.7.

15) 吉野貴紀, 松井智哉, 倉本洋 : スラブ付き C E S 造柱梁接合部の静的加力 実験, コンクリート工学年次論文集, 第 33 巻, 第 2 号, pp.1123-1128, 2011.7

16) 小島佑太, 吉野貴紀, 小山勉, 松井智哉: CES 造柱梁接合部のせん断抵抗 機構に関する基礎研究, コンクリート工学年次論文集, 第 35 巻, 第 2 号, pp.1219-1224, 2013.7

17) 小山勉，小島佑太，広瀬潤，松井智哉：CES 造柱梁接合部の構造性能に及 ぼすパネルゾーンの内蔵鉄骨フランジ幅の影響, コンクリート工学年次論 文集，第 36 巻，第 2 号，pp.1063-1068，2014.7

18) 倉本洋, 松井智哉, 今村岳大, 田口孝: CES 合成構造平面架構の構造性能, 日本建築学会構造系論文集，第 73 巻，第 629 号, pp.1103-1110, 2008.7

19) 日本建築学会 : 鉄骨鉄筋コンクリート構造計算規準・同解説, 2014, 2001.1

20) 文献調査委員会 : 短繊維補強コンクリート部材への非線形 FEM 解析の適 用に関する研究動向，コンクリート工学，Vol. 47, N o.12, pp.45-50, 2009.12

21) 竹内博幸，中根博，村上秀夫，駿河良司，古川淳，中出睦，谷垣正治：ビ ニロン繊維補強コンクリートの強度特性に関する基礎的研究 (その 1 2), 日本建築学会大会学術講演梗概集, A-1 分冊, pp.479-482, 2002.8

22) 藤本利昭, 小松博, 櫻田智之: 再生骨材コンクリートの合成構造への適用 に関する研究 一中心圧縮性状-, 日本建築学会技術報告集, 第 17 巻, 第 35 号, pp.183-186, 2011.2

23) 藤本利昭, 小松博, 櫻田智 : 再生骨材コンクリートを用いた合成構造部材 の曲げ性状, 日本建築学会大会学術講演梗概集, C-1 分冊, pp.1309-1310, 2012.9

24) 荒牧龍馬，六田莉那子，藤本利昭：CES 部材の終局せん断耐力に関する 研究, 2013 年度日本建築学会関東支部研究報告集 I, pp.617-620, 2014.2

25) 大崎広貴, 藤本利昭: CES 部材の構造性能に関寸る研究 その 5 中心圧縮 実験, 日本建築学会大会学術講演梗概集, C-1 分冊, pp.1317-1318, 2015.9

26) 日本建築学会 : 鉄筋コンクリート構造計算規準・同解説, 2010

27) 日本建築学会 : 鉄筋コンクリート造建物の勒性保証型耐震設計指針, 1997

28) 田口孝，神谷隆，倉本洋：材料特性の異なる FRC を用いた外付而震補強 工法における CES 補強柱の構造性能, 第 8 回複合・合成構造の活用に関 するシンポジウム, CD-ROM , 2009.11

29) 山口敏和, 倉本洋, 山本直輝, 松井智哉, 北村俊也, 小林義信 : CES 門形 フレームで補強した RCフレームの静的および動的載荷実験，第 7 回複合 構造の活用に関するシンポジウム, (CD-ROM), pp.39-1-8, 2007.11

30) 深津尚人, 佐藤美郷, 廣瀬泰三, 芳賀亮祐, 田口孝, 神谷隆, 松井智哉, 倉本洋：CES 外付耐震補強フレームの開発研究 その 4 補強 RCフレーム の動的載荷実験 実験概要と破断性状, 日本建築学会大会学術講演梗概集, C-1 分冊, pp.1283-1284, 2007.8

31) 日本建築学会 : 鋼構造設計規準，2005.9 


\title{
STRUCTURAL PERFORMANCE OF FIBER-REINFORCED CONCRETE
}

APPLIED TO CES MEMBERS

\author{
Toshiaki FUJIMOTO*, Rinako ROKUTA** and Hirotaka OSAKI*** \\ * Prof., Dept. of Architecture and Architectural Engineering, College of Industrial Technology, Nihon University, Dr.Eng. \\ ** Daiwahouse Industry Co., Ltd., M.Eng. \\ (Former Grad. Stud., Nihon University) \\ *** Grad. Stud., Graduate School of Industrial Technology, Nihon University
}

\section{Introduction}

Concrete-encased steel (CES) structural system consisting of fiber-reinforced concrete (FRC) and encased steels is a new composite structural system. Continuous and comprehensive studies are currently being conducted to make this system practical. In existing studies, the ultimate strength of CES columns were calculated using the strength superposition method based on test results. However, for CES columns in which FRC is used, the contribution of the confinement effect to the structural performance remains unclear. This study discusses the evaluation of the strength and confinement effect of FRC based on test results.

2. Investigation of the crack strength of $F R C$ and CES members

Material tests on FRC were conducted. Results clarified that the crack strength of cover FRC was the same as that of normal concrete. The crack strength of CES members can be calculated using the existing evaluation formula of RC members.

\section{Investigation of the bending strength of FRC}

Eccentric compression tests on FRC short columns were conducted. Selected test parameters were eccentric distance (axial load ratio) and loading directions (uniaxial or biaxial). Using the AIJ-SRC formula, the ultimate flexural strengths of all specimens were found to be at least 1.0 times that of design ultimate strengths. The application scope of this formula is for encased reinforced concrete and not for encased FRC in this study. Thus, the current AIJ-SRC formula can be conservatively used for FRC. The accuracy of fiber analysis was verified by comparing with test results.

4. Investigation of the local buckling reinforcement by FRC

Seven columns were tested under axial compression loading to investigate the effects of width-to-thickness ratio and synergistic interaction between cover FRC and encased steel. Selected test parameters were composite or non-composite columns (steel, FRC, and $(E S$ ) and width-to-thickness ratio of encased steel. Increase in steel strength by buckling due to confinement can be expected for cover FRC. Based on test results, AIJ design formulas for SRC structures can be applied to evaluate the ultimate strengths of CES columns with large width-to-thickness ratios.

\section{Conclusion}

The evaluation method of the structural performance of the CES structure was investigated. Main findings are summarized as follows.

1) Crack strength and bending strength of FRC applied to the CES structure are equivalent to those of normal concrete. However, the toughness of FRC improves according to the effect of fiber.

2) From the result of 1 ), the crack strength of CES members can be determined using the evaluation formula of RC members.

3) The stress block by AIJ-SRC standard can be estimated the strength of FRC under the axial force and bending moment. Furthermore, according to fiber analysis, the accuracy of strength evaluation improves.

4) FRC influences the local buckling reinforcement of encased steel. Therefore, FRC is believed to restrict the width-to-thickness ratio of the encased steel of CES members.1. Introduction 